\title{
Environmental Immersion and Mobile Filmmaking for Science Education: A New Zealand Pilot Study
}

\author{
Wiebke Finkler ${ }^{1}$, Fabien Medvecky², Lloyd S. Davis²
}

\author{
${ }^{1}$ Department of Marketing, University of Otago, NEW ZEALAND \\ ${ }^{2}$ Centre for Science Communication, University of Otago, NEW ZEALAND \\ *Corresponding Author: lloyd.davis@otago.ac.nz
}

Citation: Finkler, W., Medvecky, F., \& Davis, L. S. (2021). Environmental immersion and mobile filmmaking for science education: A New Zealand pilot study. Interdisciplinary Journal of Environmental and Science Education, 17(1), e2228. https://doi.org/ 10.29333/ijese/ 9155

\section{ARTICLE INFO ABSTRACT}

Received:

31 August 2020

To test whether environmental immersion and mobile filmmaking (using smartphones or tablets) can

Accepted: engender positive attitudes to science, seventeen Year 10 (14-15 years old) drama students from Queen's High School, New Zealand, were taken to Westland National Park to make videos about climate change

23 October 2020 using iPads (Immersion Group). Another fourteen students (Control Group) remained in Dunedin and also produced videos about climate change. Both groups had equal access to equipment, tutoring, incentives and footage. Yet, students in the Immersion Group were more likely to complete videos and produced videos of a higher quality. While there were no differences between the two groups in their attitudes to science before the experiment, afterwards the Immersion Group students had significantly more positive attitudes to doing science at school and beyond. The combination of environmental immersion and mobile filmmaking substantially increased interest in the environment and climate change, suggesting that it offers a promising tool for science education.

Keywords: science, education, engagement, environment, immersion, mobile, filmmaking

\section{INTRODUCTION}

Despite society's increasing dependence upon science, it remains an area that is daunting and impenetrable to many, especially the young. Internationally, there has been a significant and worrying decrease in science engagement by high school students (Osborne, Simon \& Collins, 2003; Potvin \& Hansi, 2014; Tröbst, Kleickmann, Lange-Schubert, Rothkopf \& Möller, 2016). This is especially so in New Zealand, where high school students are opting to take science subjects in ever-lower numbers in the final three years of high school, when science subjects are optional (Glukman, 2011). It is critical that this trend be reversed by engaging more young people in science (Potvin \& Hasni, 2014; Strekalova, Krieger, Damiani, Kalyanaraman \& Wang, 2018).

Environmental immersion has been identified as a potential way to engage and educate students about science (Davis, Fähnrich, Nepote, Riedlinger \& Trench, 2018). Additionally, research suggests that engagement in science increases when students: (i) participate in the production of something like a film or podcast, rather than just reading or hearing about science (Rifkin, Longnecker, Leach \& Davis, 2010a; Rifkin, Longnecker, Leach, Davis \& Orthia, 2010b; Martin, Davis \& Sandretto 2019), (ii) publish the product in the public domain, with this augmenting the engagement because students can see the worth of what they are undertaking (Saul, Kohnen, Newman \& Pearce, 2012), (iii) can ask questions of real scientists (Collins, 2010), (iv) are "hooked" on science that is initially disguised by focussing on an attractive or "sexy" topic (Trautmann, Fee, Tomasek \& Bergey, 2013), (v) deal with science conveyed through storytelling rather than fact-based learning (Davis, 2010), and (vi) can undertake activities that employ the one item that many teenagers have with them at virtually all times: their mobile devices (i.e. smartphones and tablets) (Bressler, 2006; Park, 2011).

Further, while there is evidence to show that courses about the environment based upon viewing films can enhance engagement, knowledge, and attitudes about science (e.g. Leeds, Lukas, Kendall, Slavin, Ross, Robbins, 
van Weeghe \& Berg, 2017), there has been no research to date on the value of combining environmental immersion and filmmaking.

To provide an initial test of any effect that environmental immersion might have on attitudes of high school students to science when combined with mobile filmmaking, we established a pilot study using drama students from Queen's High School in Dunedin, New Zealand. We took a group of students to Westland National Park (Immersion Group) to experience the pristine environment of the park and its two glaciers - the Fox and Franz Joseph Glaciers - which have been retreating as a consequence of global warming (Purdie, Anderson, Chinn, Owens, Mackintosh \& Lawson, 2014). The iconic glaciers were the "hook" used to engage the students in science about climate change. Another group of students (Control Group) remained in Dunedin but were supplied with footage of the glaciers and Westland National Park. Students in both groups were asked to produce short videos (3 minutes duration) about climate change using supplied iPads. All the students were given equal access to filmmaking tutoring, a climate change expert to ask questions about the science, and incentives to complete their videos. Students were told that, provided their films met a minimum quality standard, they would be screened as part of New Zealand's biennial International Science Festival and, also, made available for public viewing online. As an additional incentive to encourage students to work on this project, which needed to be conducted outside of the normal curriculum, they were told there would be a prize for the best film.

Based upon the literature reviewed above, we proposed three hypotheses to test:

H1. The Immersion Group students would react positively to being immersed in such a pristine environment, becoming engaged with their environment and more engaged with the assigned filmmaking task, and from that,

H2. The Immersion Group students would develop more positive attitudes to studying science at school compared to the Control Group students, and

H3. The Immersion Group students would develop more positive attitudes to studying science after leaving school compared to the Control Group students.

\section{METHODS}

We used a class of Year 10 drama students at Queen's High School, who had self-identified as having a strong interest in this optional subject (note: science remains a compulsory subject for students in New Zealand until the end of Year 10). This is an all-female decile 5 school based in Dunedin, New Zealand, meaning that its students come from a catchment that is in the middle of the range for socio-economic levels in New Zealand (Clark \& Das, 2014). In all, we used 31 students who were aged 14 to 15 years of age. Participation in the project was entirely voluntary and the students were free to stop participating at any time should they wish.

On 14 March 2016, all 31 students participated in a mobile filmmaking workshop held at the University of Otago's Centre for Science Communication. The 6-hour workshop covered use of iPads for filmmaking, iMovie for editing, as well as storytelling techniques for communication. To avoid any bias on our part, the girls were then divided into two groups by a third party (the headmistress), who was neither the students' teacher nor present at the workshop.

The Immersion Group ( $\mathrm{n}=17$ ) was taken by bus to Westland National Park, 555 kilometres from Dunedin, for three full days of immersion in the park from 2 April to 4 April. The park is famous for the Franz Joseph and Fox Glaciers, which have been retreating as a consequence of global warming. The students were given the task of making a three-minute video about climate change using footage that they shot themselves over the course of the three days using iPads (iPad Air 2) supplied by us. (Note: we opted to use supplied iPads rather than letting the students use their own mobile devices - smartphones and tablets - in order to standardize the experience and filmmaking capabilities for all students in this experiment). The brief required them to create a story that covered an aspect of global warming resulting from anthropogenic increases in emissions of greenhouse gases. They had 16 days to complete their videos.

The Control Group ( $n=14)$ stayed in Dunedin and were also given iPads for 16 days with an instruction to produce a three-minute video about climate change. Additionally, they were supplied with 20 minutes of raw footage of the Fox and Franz Joseph Glaciers and Westland National Park that had been filmed earlier by one of us (LSD), which they were free to incorporate into their videos.

Extra editing instruction was available to both groups (given by WF) and, on 23 March, climate change expert, Professor James Higham, spoke to both groups at the school. The students were able to ask him questions to assist them with understanding climate change and developing their stories. As part of the filmmaking exercise, the students were required to research the topic of climate change and write their own scripts for their videos.

All students took a short survey on 15 March before filmmaking began (Pre-Survey) about their perceptions 
and interest in science. We repeated this same survey on 14 April after the students had handed in their films (PostSurvey). We predicted that Immersion Group students would develop more positive attitudes than Control Group students to: (i) taking science subjects at school and (ii) the possibility of pursuing a career in science. To test that, we examined the students' responses to the following two statements:

- Science and technology are important subjects for people to study at school, and

- I intend to study science when I finish school.

An ordinal 5-point Likert Scale was used for responses $(-2=$ Strongly disagree; $0=$ Neither agree nor disagree; 2 = Strongly agree), with a further option to answer Don't know. We used one-tailed Student's t-tests assuming equal variances, with the significance level set at $P<0.05$ (McDonald, 2014).

On 5 April, at the completion of the filmmaking in Westland National Park, students in the Immersion Group were given an additional survey to assess their responses to the environment and the immersion experience itself.

At the conclusion of the study, we also carried out semi-structured interviews with ten Immersion Group students and four from the Control Group. These interviews centred around four key themes: participation in the project, attitudes to science in general, intentions about science in their further studies, and the value of filmmaking as a teaching tool.

As incentives to participate, students were told there would be a prize for the best film and that all completed videos that were of sufficient quality would be premiered as part of the International Science Festival, New Zealand's science festival that is held in Dunedin every two years, and also made available to the public through an online website (www.sciencevideo.org). Film quality was assessed independently by us (WF and LSD have each been making documentaries and teaching filmmaking for over two decades) and our scores averaged for each student's film. The requirements for screening at the festival were that videos must have: a coherent story, tolerable sound, and no music or imagery that was not the student's own unless it was a permitted use under a Creative Commons licence. Screening of the videos as part of the 2016 International Science Festival took place on Sunday 10 July 2016 before an audience of 350 .

\section{RESULTS}

In support of our hypothesis $\mathrm{H} 1$, engagement with the filmmaking activity was much higher for the Immersion Group that went to Westland National Park than the Control Group. Whereas all the students in the Immersion Group $(n=17)$ completed videos and remained part of the project throughout - from Pre-Survey (15 March) to Post-Survey (14 April) - only 8 (57\%) of the Control Group students completed videos and remained throughout. Furthermore, quality of the videos produced, a reflection of the degree of commitment of the students, was much higher overall for students in the Immersion Group: 12 $(71 \%)$ of the films produced by students that went to Westland National Park met the minimum standards needed to be screened as part of the International Science Festival, whereas only $4(50 \%)$ of the films made by students in Dunedin did so. Two students, both from the Immersion Group, were jointly awarded the prize for best film.

At the start of the pilot study, the Pre-Survey indicated there were no significant differences between the Immersion Group and Control Group students in their attitudes to studying science at school and afterwards. However, after their period of environmental immersion in Westland National Park to make their videos, students in the Immersion Group had significantly more positive attitudes to studying science both while at school $(t=1.79$, $\mathrm{df}=23, \mathrm{P}<0.05)$ and after finishing school $(\mathrm{t}=2.15, \mathrm{df}=17$, $\mathrm{P}<0.05$ ) than did the Control Group (Table 1), providing support for hypotheses $\mathrm{H} 2$ and $\mathrm{H} 3$, respectively.

This was reflected in the responses of the students in the Immersion Group to their time in Westland National Park (Table 2): all 17 of them (100\%) responded that the experience had made them interested in the environment, with $10(59 \%)$ indicating 'very much' so. There was an identical response to the effect the experience had on their interest in filmmaking. For 14 (93\%) out of the 15 of the students who responded, the experience had increased their interest in science generally. Furthermore, all the students in the Immersion Group said the experience had made them think more deeply about climate change and the environment, with 11 (65\%) responding 'very much'.

The high drop-out rate of students in the Control Group versus none in the Immersion Group suggests that the students in the Control Group were less engaged in the exercise even though, as far as practical, the two groups had the same resources, incentives, and expectations put on them (i.e., make a 3-minute film about climate change within 16 days). The only major difference was that the Immersion Group did the filming part of the exercise in Westland National Park.

Satisfaction with the filmmaking, per se, was high for both groups of students. Student A's assessment that, 'it was really fun,' was representative of the positive attitude expressed by all four girls from the Control Group who volunteered for the semi-structured interviews. A positivity towards filmmaking was also reflected in the interviews given by the ten students from the Immersion 
Table 1. Post Survey differences between the Control Group and Immersion Group regarding their attitudes to studying science at school and after they finish school. The 5-point Likert scale responses were scored from -2 (strongly disagree) to 2 (strongly agree) with the statement, with 0 indicating neither agreement nor disagreement. Students could also elect not to provide a score (don't know). The effect of environmental immersion is tested using Student's t-test, with the significance level set at $\mathrm{P}<0.05$

\begin{tabular}{lllll}
\hline Statement & & Control Group & $\begin{array}{l}\text { Immersion } \\
\text { Group }\end{array}$ & P value \\
\hline $\begin{array}{l}\text { Science and technology are important subjects for } \\
\text { people to study at school }\end{array}$ & Mean & 0.63 & 1.29 & $\mathrm{P}=0.04^{\star}$ \\
& Variance & 0.55 & 85 \\
I intend to study science when I finish school & $\mathrm{n}$ & Mean & -0.83 & 0.23 \\
& Variance & 1.37 & 0.86 \\
& $\mathrm{n}$ & 6 & 13 \\
\hline
\end{tabular}

\section{ॠ significant: $\mathrm{P}<0.05$}

Table 2. Percentage (\%) of respondents from the Immersion Group answering with each option to questions about how much the experience of being immersed in Westland National Park ("the camp") has influenced their views on the environment, science, climate change, and filmmaking

\begin{tabular}{llllll}
\hline Question & $\begin{array}{l}\text { Very } \\
\text { much }\end{array}$ & $\begin{array}{l}\text { Quite a } \\
\text { lot }\end{array}$ & A little & $\begin{array}{l}\text { Very } \\
\text { little }\end{array}$ & Not at all \\
\hline $\begin{array}{l}\text { How much has this camp make you interested in the } \\
\text { environment? }\end{array}$ & 58.8 & 29.4 & 11.8 & 0 & 0 \\
$\begin{array}{l}\text { How much has this camp make you interested in } \\
\text { science? }\end{array}$ & 20.0 & 60.0 & 13.3 & 0 & 6.7 \\
$\begin{array}{l}\text { Did the camp help you think more deeply about cli- } \\
\text { mate change and the environment? }\end{array}$ & 64.7 & 29.4 & 5.9 & 0 & 0 \\
$\begin{array}{l}\text { How much has this camp make you interested in film } \\
\text { making? }\end{array}$ & 58.8 & 29.4 & 5.9 & 5.9 & 0 \\
\hline
\end{tabular}

Group, with Student B's comment being an example, 'I've always liked film and media, so doing this was like a really big thing for me and it helped me out a lot.'

The differences between the two groups that became apparent through the interviews related mostly to the effect on the Immersion Group students of being in the national park surrounded by nature, providing additional support for hypothesis $\mathrm{H} 1$. According to Student C, this was an excellent way to learn, 'like actually going up to the glaciers and like actually experiencing it firsthand.' Further, this environmental experience affected the way that she viewed science, showing her, 'a more practical version of science and like how it affects the actual world and not just how it creates things.' Another of the Immersion Group students, Student D, described being in unspoiled nature as the best part of the whole experience, 'seeing all the beautiful nature, like the waterfalls. That was great.' This was echoed by yet another, Student E, who contrasted the experience of the national park with that of being in Dunedin: 'Dunedin, it's pretty much just buildings, and over there it's just nature everywhere.'
In sum, the strong consensus that emerged from the semi-structured interviews with the Immersion Group students was that the experience of being in Westland National Park heightened their attitudes to the environment and climate change, and, as a consequence, to science as well.

\section{DISCUSSION}

Both the Immersion and Control Group students had equal access to those elements known to enhance engagement. That is, they produced their own film about a science topic (Martin, et al, 2019), which was published in the public domain (Saul, et al, 2012) by being shown at an international science festival and online. New Zealand's iconic glaciers were used as a "hook" to get the students interested in the science of climate change by examining the threats that global warming poses for the glaciers (Trautmann, et al, 2013). The science in their films was conveyed through storytelling (Davis, 2010), and the films were produced using mobile devices, which are especially attractive for students (Park, 2011). Furthermore, the 
students had access to a real scientist to ask questions (Collins, 2010) when producing their films.

Nevertheless, the results of our study supported our hypotheses that attitudes of students to science are enhanced when environmental immersion is combined with using mobile filmmaking to create stories about an aspect of science. The two groups differed only in their degree of environmental immersion and those students that actually went to the national park were more engaged in the exercise, performed better, and afterwards had significantly enhanced attitudes to taking science subjects at school and after leaving school: a clear and remarkable response to the intervention. Cognitively, humans are known to be affected by a connection with the natural environment (Seaman, 2015) and the finding from this study - that students respond positively to the effect of being immersed in a pristine environment - is consistent with outcomes from environment schools and outdoor education courses (Finn, Yan \& McInnis, 2018). In fact, the concept of ecopedagogies has emerged as a way of advancing the United Nation's vision for progressive educational systems (Whiting, Konstantakos, Misiaszek, Simpson, \& Gabriel Carmona, 2018).

Our results are also consistent with the educational philosophy articulated by Hadzigeorgiou (2016), which proposes that a combination of storytelling and an experience that creates "wonder" about the environment should result in higher levels of engagement with science. This occurs because the students' aesthetic appreciation of the natural world evokes wonder about science ideas that are derived from natural forms and phenomena (Hadzigeorgiou \& Skoumios, 2013). This would suggest that our Immersion Group students' experience of the pristine forests and glaciers of Westland National Park provoked wonder in them, which when combined with using storytelling to make a film about the natural phenomena they were observing, disposed them to have more positive attitudes to science. Hadzigeorgiou (2012) showed experimentally that school students, similarlyaged to those in this study, became more engaged with science subjects when teachers deliberately stimulated wonder in them.

There is an argument that a transformation from conventional teacher-centred learning to active studentcentred learning, as occurred in our study through the use of mobile filmmaking, should have brought positive benefits to both groups, irrespective of their degree of environmental immersion, in terms of attitudes to science (Hasanah, 2020). While, indeed, both the Immersion and Control groups of students professed that they enjoyed filmmaking as a form of communication and learning, it was striking from a pedagogical perspective that this did not in itself enhance their attitudes to science. That is, it was the environmental immersion not the filmmaking, per se, that resulted in students having more positive attitudes to science. One factor that may have influenced this result is that these exercises needed to take place outside the classroom and normal curriculum. By contrast, when mobile filmmaking is integrated into the classroom as part of the regular curriculum, it may be a more effective tool on its own to enhance students' attitudes to science (Martin, et al, 2019).

\section{CONCLUSION}

The novel outcome of this study is that environmental immersion in places like national parks, when combined with generating a form of environmental communication through mobile filmmaking, can generate a halo effect that results in more positive attitudes to science. While we need to keep in perspective that this is but a single pilot study utilising a relatively small sample size, it is nevertheless encouraging that this type of environmental communication for learning (filmmaking embedded in nature) had such a significant and positive effect on the students' attitudes to science education both at school and beyond. As Miller (1999) notes, using a control group against which to compare any interventions is not especially common in education research and this should provide some confidence in the direction of our results. Certainly, the results of the pilot study are encouraging, in terms of affecting students' attitudes to science, and suggest that larger-scale and more nuanced studies are warranted.

\section{LIMITATIONS AND RECOMMENDATIONS}

As effective as environmental immersion combined with filmmaking may be as a potential teaching tool, there are logistical challenges to turning this approach into a workable option for schools. Taking students into pristine and remote natural areas for days at a time, as was done here, is expensive to scale across the whole education system. A fertile ground for future research would be to determine whether similar benefits may be derived from more limited environmental immersion, whereby mobile filmmaking about the environment is combined with day trips to places such as local nature reserves or botanical gardens. Experiences available from such an 'immersionlite' approach might still alter the attitudes of students to the environment and, through a halo effect, to science itself.

As another option, if it is too expensive to "take students to the mountains," so to speak, perhaps we can "bring the mountains to them"? Two possibilities 
that would allow for this are: (i) the use of Virtual Reality (VR) experiences viewed using cheap headsets that work in combination with the students' own smartphones (Strekalova, et al, 2018), or (ii) $360^{\circ}$ videos that can be viewed on the students' own mobile devices, which, as they incorporate gyroscopes and accelerometers, allow users to pan around inside a $360^{\circ}$ video simply by turning their smartphones (Reyna, 2018; Smith, 2020). Both VR and $360^{\circ}$ videos can provide an immersive experience, offering the potential for being an inexpensive means of leveraging the benefits of "environmental immersion" that were observed in this study for inducing science engagement.

At the very least, our results suggest that more research is warranted on the effect of environmental immersion for promoting positive attitudes to science amongst high school students. Potentially, this could help arrest the alarming drop in the uptake of science subjects by students in New Zealand (Glukman, 2011) and, by extension, worldwide.

\section{NOTES}

1. The winning films are viewable at www.sciencevideo. org

\section{ACKNOWLEDGEMENTS}

This research was funded by an Unlocking Curious Minds grant from New Zealand's Ministry of Business Innovation and Enterprise. We wish to thank the staff and students of Queen's High School who participated in the project and, in particular, Ms Terry McTavish, the Year 10 drama teacher. Professor James Higham generously provided his time to speak to the students and answer their questions. The iPads were supplied by the University of Otago, Cyclone Computers Ltd kindly assisted with the provision of prizes, and the organisers of the New Zealand International Science Festival enthusiastically agreed to have the premiere of the girls' videos as part of the festival. Approval for this research was obtained from the Ngai Tahu Research Consultation Committee and the University of Otago Ethics Committee. We would also like to acknowledge the helpful input from three anonymous referees.

\section{REFERENCES}

Bressler, D. (2006). Mobile Phones: A New Way to Engage Teenagers in Informal Science Learning, in J. Trant and D. Bearman (eds.). Museums and the Web 2006: Proceedings, Toronto: Archives \& Museum Informatics, published March 1, 2006 at http://www.archimuse.com/mw2006/papers/ bressler/bressler.html

Clark, J., \& Das, S. R. (2014). Evaluating the Weights and Factors Used in the New Zealand School Decile Funding
System. Working Papers in Economics 14/30, University of Canterbury, Department of Economics and Finance.

Collins, S. (2010). The secrets of engaging teens with science. 2020 Science http://2020science.org/2010/04/13/im-ascientist-get-me-out-of-here/

Davis, L. S. (2010). Science communication: A "Down Under" Perspective. Japanese Journal of Science Communication, 7, 65-71.

Davis, L. S., Fähnrich B., Nepote A. C., Riedlinger M., \& Trench, B. (2018). Environmental Communication and Science Communication-Conversations, Connections and Collaborations Environmental Communication, 12(4) 431437. https://doi.org/10.1080/17524032.2018.1436082

Finn, K. E., Yan, Z., \& Mclnnis, K. J. (2018). Promoting Physical Activity and Science Learning in an Outdoor Education Program. Journal of Physical Education, Recreation \& Dance, 89(1): 35-39, DOI: 10.1080/07303084.2017.1390506

Glukman, P. (2011). Looking Ahead: Science Education for the Twenty-First Century: A report from the Prime Minister's Chief Science Advisor. Office of the Prime Minister's Science Advisory Committee. 68pp.

Hasanah, U. (2020). Key definitions of STEM education: Literature review. Interdisciplinary Journal of Environmental and Science Education, 16(3), e2217. https://doi.org/ $10.29333 /$ ijese/8336.

Hadzigeorgiou, Y. P. (2012). Fostering a sense of wonder in the science classroom. Research in Science Education, 42, 9851005.

Hadzigeorgiou, Y. (2016). Imaginative science education: The central role of imagination in science education. Switzerland: Springer International Publishing.

Hadzigeorgiou, Y., \& Skoumios, M. (2013). The development of environmental awareness through school science: Problems and possibilities. International Journal of Environmental \& Science Education, 8, 405-426.

Leeds, A., Lukas, K. E., Kendall, C. J., Slavin, M. A., Ross, E. A., Robbins, M. M., van Weeghe, D., \& Berg, R. A. (2017). Evaluating the effect of a year-long film focused environmental education program on Ugandan student knowledge of and attitudes toward great apes. American Journal of Primatology 79, e22673 1-9 DOI: 10.1002/ajp.22673

Martin, K. M., Davis, L. S., \& Sandretto, S. (2019). Students as storytellers: Mobile-filmmaking to improve student engagement in school science. Journal of Science Communication, 18(05), A04. https://doi. org/10.22323/2.18050204.

McDonald, J. H. (2014). Handbook of biolological statistics. Baltimore: Sparky House Publishing.

Miller, D.W. (1999). The Black Hole of Education Research. The Chronicle of Higher Education August 6 1999, Section: Research \& Publishing Page A17

Osborne, J., Simon, S., \& Collins, S. (2003). Attitudes towards science: A review of the literature and its implications. International Journal of Science Education, 25(9), 1049-1079. doi:10.1080/0950069032000032199

Park, Y. (2011). A pedagogical framework for mobile learning: Categorizing educational applications of mobile technologies into four types. The International Review of Research in Open and Distributed Learning, 12(2), 78-102.

Potvin, P., \& Hasni, A. (2014). Interest, motivation and attitude 
towards science and technology at K-12 levels: a systematic review of 12 years of educational research. Studies in Science Education, 50(1), 85-129. doi:10.1080/03057267.2014.881626

Purdie, H., Anderson, B., Chinn, T., Owens, I., Mackintosh, A., \& Lawson, W. (2014). Franz Josefand Fox Glaciers, New Zealand: Historic length records. Global and Planetary Change, 121, 41-52. http://dx.doi.org/10.1016/j.gloplacha.2014.06.008

Reyna, J. (2018). The potential of 360-degree videos for teaching, learning and research. 12th International Technology, Education and Development Conference. https:// doi.org/10.21125/inted.2018.0247

Rifkin, W., Longnecker N., Leach J., \& Davis L. (2010a). Blogging biology \& podcasting physics: Authentic learning via student creation of new media. Proceedings of the 16th UniServe Science Annual Conference, University of Sydney, Sept 29th to Oct 1st, 2010, p 113-115.

Rifkin, W., Longnecker, N., Leach, J., Davis, L., \& Orthia, L. (2010b). Students publishing in new media: Eight hypotheses - a house of cards? International Journal of innovation in Science and mathematics Education, 18(1), 43-54.

Saul, W., Kohnen, A., Newman, A., \& Pearce, L. (2012). Front Page Science: engaging teens in science literacy. Arlington, Virginia: NSTA Press.

Seaman, D. (2015) Situated cognition and the phenomenology of place: lifeworld, environmental embodiment, and immersion-in-world. Cognitive Processing, 16(Suppl 1), 389392.

Smith, H. P. (2020). The role of 360-degree Cameras, Augmented Reality, and Virtual Reality in Sociology \& Criminology: the future of innovation. Proceedings of Research World International Conference, Sydney, Australia, 5-6 June 2019, pp.1-3.

Strekalova, Y. A., Krieger J. L., Damiani R. E., Kalyanaraman S., \& Wang D. Z. (2018). Old media, new media, and public engagement with science and technology. Pennsylvania: IGI Global.

Trautmann, N. M., Fee, J., Tomasek, T. M., \& Bergey, N.R. (eds). (2013). Citizen Science: 15 lessons that bring biology to life, 6-12. Arlington, Virginia: NSTA Press.

Tröbst, S., Kleickmann, T., Lange-Schubert, K., Rothkopf, A., \& Möller, K. (2016). Instruction and students' declining interest in science: An analysis of German fourth- and sixthgrade classrooms. American Educational Research Journal, 53(1), 162-193 DOI: 10.3102/0002831215618662

Whiting, K., Konstantakos, L., Misiaszek, G., Simpson, E., \& Gabriel Carmona, L. (2018). Education for the sustainable global citizen: What can we learn from stoic philosophy and freirean environmental pedagogies? Education Sciences, 8(4), 204; https://doi.org/10.3390/educsci8040204 